\title{
THE CONSPIRACY OF BRAINWASHING: THE EXPERIENCES OF THE FIRST AND THE SECOND COLD WAR
}

\author{
Gintaras Aleknonis ${ }^{1}$
}

\begin{abstract}
With the recent rise of a new confrontation between the East and the West, the convergence of different understandings of brainwashing emerges as a problem of political communication and poses a challenge for information security. The principle objective of this paper is to present a contemporary understanding of brainwashing, determine its propaganda potential, and provide educated guesses about successor concepts, which could be traced back to the origins of brainwashing. Therefore, the article describes the 'classical' Western understanding of brainwashing; looks for the potential equivalents of brainwashing on the other side of the Iron Curtain; reveals the rebirth and transformations of the concept in post-communist countries during the period of time, when brainwashing in the West had already came out of fashion; notes to the potential misunderstandings between the new and old democracies, which arise because of the different interpretation of brainwashing.The contemporary comprehension of brainwashing continues to alternate between instrumental and political understanding. The broadened concept becomes more blurred, although the lack of precision compensates the potential loss of mystery and allows the brainwashing to preserve an image of an almighty technique.
\end{abstract}

KEY WORDS: Brainwashing, Propaganda, Conspiracy theory, Cold War, Mind control.

\section{INTRODUCTION}

During the Cold War, the concept of brainwashing had different meanings on the opposing sides of the Iron Curtain. In the country of its origin, the USA, brainwashing was initially described as the hostile ambition of the communists "to change a mind radically so that its owner becomes a living puppet - a human robot without the atrocity being visible from the outside" (Hunter, 1956, p. 309). In the Soviet Union or, rather, in Central European countries, occupied by the communists, where the presumed processes of brainwashing were applied on innocent people, brainwashing was a scarcely

\footnotetext{
1 Faculty of Media, Kiel University of Applied Sciences, Kiel, Germany; Faculty of Communication, Vilnius University, Vilnius, Lithuania, E-mail gintaras@gmail.com
} 
used concept without a clear meaning and understood as an imaginative abstract idea, or as an extension of various propaganda activities.

It is nothing new or extraordinary for the same concept to have varying meanings in distinct cultures, or during different time periods. However, with the recent rise of a new confrontation between the East and the West, which is often presented as the Second Cold War, the convergence of different understandings of brainwashing emerges as a problem of political communication and as a challenge for information security. Only precise descriptions of prospective opponents, their attack targets and clear identification of potential risks can help find an adequate response strategy. In the West, most of the new invented descriptions of enemy hostilities are expressive and terrifying, although lacking in rational meaning. 'Nonconventional', 'special' or 'hybrid' wars, 'little green men' or 'guerrilla geopolitics' are routinely used to describe, but not to explain, Russian military tactics. NATO Secretary General Anders Fogh Rasmussen speaks about Russia employing "a new different type of warfare" (Rasmussen, 2014), his opponent, the chief of the General Staff of the Armed Forces of Russia Valery Gerasimov notices "a tendency toward blurring the lines between the states of war and peace. Wars are no longer declared and, having begun, proceed according to an unfamiliar template" (Gerasimov, 2013).

The 'unfamiliar template' is expected to be composed of new sophisticated strategies, although studies of great military commanders of the past reveal, that most of the military novelties are based on the same classical principles of united command, surprise actions, or simplicity, to name only a few. The study of brainwashing can serve as a sound acknowledgement of a skeptical attitude towards military novelties and help to track the emergence of the new-old strategies or instruments, which are inherited from the First Cold War and could be successfully used under new conditions. The brainwashing was an important and hardly replaceable instrument of propaganda of the 1950 's and 1960's, it would therefore be rational to presume, that something similar could be emerging at the outset of the Second Cold War.

The principle objective of this paper is to present a contemporary understanding of brainwashing, determine its propaganda potential, and provide educated guesses about successor concepts, which could be traced back to the origins of brainwashing. Therefore, we will: (1) describe the 'classical' Western understanding of brainwashing, which is inherited from the First Cold War; (2) look for the potential equivalents of brainwashing on the other side of the Iron Curtain, principally referring to the experiences from the Soviet occupied Lithuania; (3) reveal the rebirth and transformations of 
the concept in post-communist countries during the period of time, when brainwashing in the West had already came out of fashion; (4) note to the potential misunderstandings between the new and old democracies, which arise because of the different interpretation of brainwashing.

The present article could be attributed to the critical tradition of communication research, which "seeks to understand the taken-for-granted systems, power structures, and beliefs-or ideologies-that dominate society, with a particular eye to whose interests are served by these power structures" (Littlejohn, Foss, Oetzel, 2017, p. 43-44).

\section{THE LEGACY OF THE FIRST COLD WAR}

Edward Hunter, the American journalist and author, who rigorously benefited from his membership in intelligence community, is generally considered to be the author of the word 'brainwashing. His skillfully written books (Hunter, 1951; 1956; 1962) created a mysterious story, supported by the detailed confessions of American prisoners of war (POW) and had significant elements of horror. The word was coined at a proper time, as a relevant response to the overwhelming public discontent, which quickly overshadowed the joy of the Allied victory in the Second World War. At that time, the American public was generally worried by two threats, which were considered as imminent: takeover by the communists and the danger of a nuclear conflict. Under these circumstances, brainwashing - a mysterious way to press people to radically change their beliefs - could become not only a miracle answer to the essential questions of the time, but simultaneously turn into a third threat, and become some sort of a mental nuclear bomb. In a highly competitive atmosphere of threats and insecurity, brainwashing won the battle for the minds and hearts of the people, as the universal explanation of the Cold War disasters. The popular lack of knowledge about communism only increased the fear, as Andreas Killen and Stefan Andriopoulos imply: "knowledge deficit became a structural element of the discourse about brainwashing" (Killen, Andriopoulos, 2011, p.10). The concept of brainwashing gained its place in popular culture, was widely used by politicians, however, it received no appropriate scientific endorsement.

The popular story of brainwashing was based on the narrative of everlasting fight between communism and capitalism. It was presented, that communists were ready to employ even the most brutal techniques in order to suppress free will and transform a person into a slave of a new regime; 
while democrats trusted freedom. Brainwashing served as an excellent tool for demonization of the enemies, helped to increase division between good and evil, facilitated the scapegoating. In popular understanding, brainwashing became attractive, because it started "with a grain of truth embedded in pre-existing societal beliefs" (Berlet, 2009, p. 5) and provided the "believers with knowledge (and therefore a degree of control), an enemy against which to fight, and a purpose that is linked to a grand historical narrative" (Lee, 2011, p. 9).

The popular media served as important channels for the dissemination of the idea of brainwashing. From all the flow of the images of brainwashing into popular culture, we would single out a bestselling thriller novel "The Manchurian Candidate" by Richard Condon, which was published in 1959, and screened twice. The book presents a 'mature' popular understanding of the concept and reveals unconventional mental danger. As one of the protagonists of the novel, Bennett Marco explains to Raymond Shaw, who became a victim of enemy brainwashing: "we need you to think of yourself as some kind of time bomb [...] They got inside your mind" (Condon, 2004, p. 219).

When the concept of brainwashing came into being, the popular public was ready to accept it, however, we should not miss the internal appeal of brainwashing, which rested in the very construction of the concept, and could be explained as a peculiar example of conspiracy theory. Conspiratorial roots help to explain the longevity of brainwashing.

At least during the first decade of existence, the brainwashing was broadly accepted by political, military, or intellectual establishment as well. The process coincided with so called McCarthyism period in the USA, which is known as time of ruthless fight against communism and its influence inside the country. Conspiratorial thinking, or 'paranoid style' (Hofstadter, 1996) could be used as explanation of the prevailing mood, and the brainwashing finds an honourable position in this context. A nearly universal support gained by the brainwashing as an 'official' conspiracy theory could be explained not only by the lack of knowledge, the establishment benefited from conspiratorial attributes of the brainwashing as well. The creation and dissemination of conspiracy theories by authorities or their advisories is nothing new or extraordinary. However, we need special investigation to establish secret ties and define, how the conspiracy theory was invented. The story of brainwashing raises serious doubts, that one journalist was so successful to coin a word, which, with the assistance of a few popular books, a bestselling novel and a blockbuster movie, imposed a comprehensive way 
of thinking, which became an 'emblem of Cold War paranoia' (Holmes, 2016, p. 285). Timothy Melley, who provided an extensive analysis of 'the covert sphere as a cultural imaginary', is strict: "the concept of brainwashing was from the beginning a creation of the CIA, which invented and disseminated the idea as part of a propaganda campaign to fuel public anxiety about Communist methods" (Melley, 2012, p. 57). The arguments to support the opinion are based on the well documented links of Hunter with the CIA, but they lack solid content. Matthew W. Dunne is more explicit: "All of the available evidence indicates that Hunter, like several other cold warriors of the same mind in the government, genuinely believed that Communist brainwashing existed and posed a real threat to the United States" (Dunne, 2013, p. 24).

Brainwashing was perceived as a useful tool in political struggle of that time. Competition between the East and the West was one of the most important topics of the day and comprehended not only the international politics, but ran through nearly all civic issues. Brainwashing was like a 'double sided sword' with risky side effects: it could encourage escape from responsibility, devalue personal determination and free will, incite defeatism and civic impotence. In the shadow of brainwashing, the will of dangerous outside forces pretended to be overwhelming and irresistible. At that point, the possible impact of brainwashing on the society reminded of a conspiracy theory, which "fosters two paradoxical tendencies: apathy and political extremism. Both of these propensities are unhealthy for the political community" (Lee, 2011, p. xiii).

From the moment of its birth, brainwashing became a challenge for the research community, which was expected to give a comprehensive answer whether the threat is real, or it is a creation of suspicious imagination. The scientific verdict was delivered quickly, but the decision was not unanimous. As Ron Robin observes, "interpretations of the American POW experience do not divide easily into false - political - and true - scientific - accounts" (Robin, 2009, p. 164). The endorsement of the danger of brainwashing or skeptical attitudes towards it was influenced by traditions of conflicting research schools, affected by funding of scientific activities, or determined by personal ideological and moral attitudes of the researchers.

Albert D. Biderman studied servicemen, who returned from the Chinese and North Korean prisons. His conclusions asserted, that methods used for brainwashing "included nothing which was not common practice to police and intelligence interrogators of other times and nations, where restraints precluding such tactics were not in force" (Biderman, 1957, p. 618). 
Another cautious investigator, psychiatrist Robert Jay Lifton, wrote a book, based on in-depth interviews with people, who underwent brainwashing in communist captivity, and provided an extensive psychiatric evaluation of Chinese Communist 'thought reform'. The author concluded: "Behind this web of semantic (and more than semantic) confusion lies an image of 'brainwashing' as an all-powerful, irresistible, unfathomable, and magical method of achieving total control over the human mind. It is of course none of these things, and this loose usage makes the word a rallying point for fear, resentment, urges toward submission, justification for failure, irresponsible accusation, and for a wide gamut of emotional extremism" (Lifton, 1989, p. 4).

Today, the skeptical attitude towards brainwashing is a scientific standard, during the period of the birth of the concept, when boundaries of the subject were blurred, scientific attitudes, which are unchallenged today, felt a fierce competition. A large group of scholars were scared by communist activities; especially cautious were researchers, who had first-hand experience with Nazi or communist regimes. Psychiatrist Joost A. M. Meerloo assured: "now we are beginning to see ever more clearly how the totalitarians use menticide: deliberately, openly, unashamedly, as part of their official policy, as a means of consolidating and maintaining their power, though, of course, they give a different explanation to the whole procedure it's all confessions of real and treacherous crimes" (Meerloo, 1956, p. 19).

The belief, that brainwashing is a modern technique, which opens the new scientific horizons, could be attributed to the caution of medical professionals, who were dedicated to establish links between human physical and mental conditions. We should note a significant influence of Russian academic Ivan Pavlov, whose ideas about respondent conditioning were exploited by Soviet establishment, and mysterious stories about successful use of Pavlovian techniques by communist secret services spread in the West from the 30's. In the book "Battle for the Mind" British psychiatrist William Sargant insisted "that simple physiological mechanisms of conversion do exist, and that we therefore have much still to learn from a study of brain function about matters that have hitherto been claimed as the province of psychology or metaphysics" (Sargant, 1957, p. xxviii). It would be sinister to judge the advocates of brainwashing according to today's standards and contemporary knowledge: at a time medical community shared great expectations in potential of neurosurgery and its ability to treat mental disabilities.

In the 50's brainwashing was not a lonely idea, the diversity of competing definitions confirm, that the popularity of the concept was not accidental. 
If Hunter had missed his chance to invent brainwashing, there were a lot of names 'in waiting'. For Lifton the brainwashing was confusing, he preferred a less pretentious 'thought reform'; Meerloo stayed loyal to his brainchild 'menticide' (i.e., 'mental genocide'); Edgar. H. Schein was more interested in "the Chinese methods, best described by the label "coercive persuasion"' (Schein, 1960, p. 3). Other names of the phenomena (propaganda, persuasion, indoctrination, or reeducation), where less inventive. This peculiar competition indirectly confirms observation by Marcia Holmes: "as the growing historical literature on 'brainwashing' makes clear, it is a myth that 'brainwashing' ever had a specific, widely accepted definition" (Holmes, 2016, p. 286).

The concept of brainwashing was primary designed for internal American use, and gained deep roots in the West, because of its potential to explain mysterious events, which occurred to unfortunate detainees in the obscure communist system. Simultaneously, brainwashing evolved into a peculiar weapon, which was used to inflate the threat of the new enemies and to defend the honour of the victims, who succumbed to the pressure of the communists. Brainwashing was presented as a technique, to which nobody could resist. However, over time, the impact of brainwashing on the American society was devalued, as Killen and Andriopoulos noticed, "The Cold War dream, or nightmare, of brainwashing as a method of absolute mind control proved mythical" (Killen, Andriopoulos, 2011, p. 12).

\section{EXPERIENCES ON THE OTHER SIDE OF THE IRON CURTAIN}

On the other side of the Iron Curtain, the concept of brainwashing was scarcely known and never employed by the Soviet propaganda. The fact that, brainwashing is a translation of Chinese concepts only alienated Soviet communists, as the Sino-Soviet split at the height of the Cold War "left bad memories and produced myths of innocence on both sides" (Lüthi, 2008, p. 1). The Chinese footprint on brainwashing on the rise of it stimulated a skeptical attitude of the Soviets towards the concept. Nevertheless, it is puzzling, that communists had not used the potential of brainwashing in their extensive propaganda campaigns, as it would be natural for them to adjust the concept to their needs. The conversion of the abusive concept, which was invented by the capitalists, occurred to be an unachievable goal, as brainwashing could be useful for propaganda only in cases, when it was presented as an enemy's weapon. It would be reckless to acknowledge, that communists use brainwashing against their own citizens. The communist 
leadership promoted the idea, that the working class should be enlightened in order to join the struggle against capitalism; the transformation of the old methods of propaganda into a new brainwashing was unacceptable, as it could be interpreted as a weakness of the system.

As intellectual connections between the two sides during the Cold War were nonexistent, the Soviet ideologues saw no need to fight against the concept of brainwashing, the profound decision was simply to conceal it. The communists were skillful protectors of innocent citizens from the negative influence and harmful ideas, in the case of brainwashing they, undoubtedly, succeeded. What Westerners understood as brainwashing, in reality existed in the East, but was identified under other names. Referring to the examples from the Soviet occupation of Lithuania, we argue, that under communists, brainwashing could be distinguished as: imprisonment and interrogation by the KGB; treatment of dissidents in special psychiatric clinics; the extended understanding of various propaganda activities.

As the concept of brainwashing was facilitated by the Korean War and was coined as an explanation of POW treatment by the communists, it would be logical to presume, that the practice of brainwashing was simultaneously employed by the communists on the other fronts. The staged communist 'revolutions' in Central Europe experienced a desperate need of converts to the new faith, as well as the enemies of the people. The infamous show trial of Cardinal József Mindszenty in Hungary, or the American citizens Robert Vogeler in Hungary and William Oatis in Czechoslovakia served as illustrations of forced and involuntary change of mind, which refreshed memories of infamous Communist show trials of the 30's. The threat of brainwashing was so real, that the Polish cardinal Adam Stefan Sapieha even "issued a statement declaring that if he were arrested, no one should believe in the authenticity of any statements or 'confessions' he made afterward" (Applebaum, 2012, p. 228).

However, examples of 'brainwashing in a prison cell' from Lithuania or other Soviet occupied states point to essential differences between brainwashing and coercive interrogation applied in KGB prisons. If brainwashing is considered to be a sophisticated combination of mental and physical pressure, KGB in Lithuanian relied on the latter. Soviet secret services were well organised, the use of torture was classified and no documents about misdeeds were left (Anušauskas, 2000). Therefore, the descriptions of interrogation techniques is based on the evidence of survived witnesses, whose testimonies include different beatings, humiliations, extremely long interrogations, permanent bright lightning in the cells, not to 
mention overcrowded prisons, lack of sanitation and medical help, or poor nutrition (Anon, 1979; Anon, 1999; Anušauskas, 2012).

The distinctions between communist brainwashing in North Korea and much more brutal behavior of KGB officers in Central Europe could be explained by the different conditions. American POW were brainwashed far from the front line, in the 'safe' prison camps, the interrogators had no time limits, the desirable confessions had only propaganda value. In Soviet occupied states, the interrogations happened on the front line, the same officers were fighting, killing and interrogating. They were in a hurry, the confessions had great operative value, could lead towards discovery of secret ties and sites, identification of undercover fighters. The conversions and public confessions were left for the future, and rarely happened, as the captives were either murdered or sent to concentration camps. KGB methods reminded more of the infamous Nazi secret state police the Gestapo, than brainwashing. The captured freedom fighters were volunteers with high motivation, and the communist repression system often left no escape routes for them, except death. On the contrary, the drafted American soldiers usually need not only military training, but motivation sessions, what during the first stage of the Korean war was overlooked by American military command and later provoked discussions about "rapid moral decay" (Carruthers, 2009, p. 212).

The brutal Communist activities in Central Europe confirm that brainwashing is more a phantasy of the Cold War or, rather, a successful conspiracy theory, than a reality. After the death of Joseph Stalin, when the KGB methods became less cruel and the image of brainwashing was slowly fading in the West, the actual methods of interrogation began to remind of brainwashing more than during any other period. However, these methods remained rather primitive, based on total isolation from the outside world; anxiety about the future; psychological pressure and spying of the fellow prisoners (Bukovsky, Gluzman, 1974).

Research on the Lithuanian resistance movement creates an impression, that KGB officers felt no need to brainwash. The local Communist party leaders, responsible for propaganda efforts, expressed different interests: public confessions or trials of the opponents was important material for propaganda. Since the end of 1944, the leaders of the Lithuanian Communist party tried to influence the local KGB commanders to proceed with the public trials. The passiveness of power structures leads towards the conclusion that brainwashing of Lithuanian resistance fighters was far from successful; interrogators had no results to show (Bagušauskas, 2004). 
After the death of Stalin, the Soviet occupiers began to demonstrate some restraint: mass imprisonment or incarceration in concentration camps came 'out of fashion'. Less brutal behavior of interrogators, changeover from physical torture to psychological ways of pressure were signs of the moderation. What was understood in the West as the brainwashing, in the Soviet occupied lands moved from the prison cell to the hospital ward. The Soviet psychiatry, which "had become instruments for manipulating the minds and souls of defenseless citizens" (Robin, 2009, p. 168), looks like a perfect illustration of brainwashing, and could confirm even the most harsh predictions of promoters of the concept. At the heights of the Cold War, nobody needed a sharp imagination to expect innocent people to be forcefully incarcerated in mental hospitals, where special treatment helped to relieve them from 'dangerous ideas'. However, the disclosures of misuse of psychiatry under communists reveals only occasional parallels with brainwashing. The questions of misuse of psychiatry under communists were brought into public discourse at a time, when the popularity of brainwashing was fading down in the West, and trust in its miraculous qualities evaporated. The problem of Soviet psychiatry was framed as a misuse of medical isolation and as an illegitimate substitute of political imprisonment, but not as a change of mind. On the other hand, Soviet authorities were never pleased with the results of the treatment of dissidents in mental hospitals; there were no reports about miraculous 'recoveries'. The dissidents who, after harsh treatment, were allowed to emigrate to the West, usually were declared mentally healthy.

The Western understanding of brainwashing and the misuse of psychiatry in the Soviet Union are closely tied to the same Pavlovian roots. As Robert van Voren notices, "Pavlov's behaviorism was enforced as the only acceptable ideology of mental health practice and research in the Soviet Union" (van Voren, 2015, p. 47). Despite similarities, the direct comparison of misuse of psychiatry against dissidents in the Soviet Union and effectiveness of brainwashing of American POW in North Korea is questionable. The misuse of psychiatry was targeted only against Soviet citizens; there were no cases of hospitalization of the foreigners in mental hospitals for political reasons. The failures of psychiatry to convert dissidents into communists, could serve as another argument against the effectiveness of brainwashing.

Soviet psychiatry claimed that only mentally ill people were isolated and treated in the hospitals. The problem was based on the different understanding of mental illness in the East and in the West. The researchers of the Soviet system argued, that psychiatry, under the influence of communist 
ideology was ready to consider every person, who stood out of the system, to be mentally ill (Trimakas, 1981), and saw no difference between dissidents and the mentally ill (Kuklyte, 2007). Lithuanian psychiatrist and dissident Algirdas Statkevičius, who was treated in special psychiatric hospitals, quotes the chief psychiatrist of Lithuania, Judelis Gutmanas: "If a person does not value his life and tries to cross the border of the Soviet Union illegally, I have no doubts about his diagnosis. He is a schizophrenic" (Anon, 1999, p. 73).

The parallels of psychiatric misuse and brainwashing leads towards the conclusion, that isolation of dissidents in mental hospitals was an important factor, which shaped the understanding of 'a normal Soviet citizen', who was happy with their everyday life. Those, who publicly showed critical attitudes towards communism, who encouraged others to stand against injustice, or straightforwardly fought against the Soviet system, were not simply dissidents, but were sick. As Tomas Vaiseta notes, "the normal Soviet citizen' is a person, who accepts the rules of a game, which are created by authoritative discourse" (Vaiseta, 2014, p. 195). The image of mentally sick dissidents became an important building block of a complex narrative, which was cautiously promoted by the Communist party.

The search for equivalents of brainwashing under Soviets should include the everyday Communist propaganda activities as well. However, it is important to resist the temptation to equalize brainwashing and propaganda. Communist propaganda activities were effective and theoretically conceptualized. At the birth of the Russian communist movement, Georgi Plekhanov proposed a two-step model of dissemination of revolutionary ideas and explained the distinction between agitation and propaganda: "A propagandist presents many ideas to one or a few persons; an agitator presents only one or a few ideas, but he presents them to a mass of people" (quoted in: Lenin, 1902). Binary understanding of propaganda was theoreticized long before Paul Lazarsfeld and associates presented the two-step flow of communication hypothesis. Propaganda was understood by communists as deep personalised persuasion, which could be associated with education or brainwashing, while their perception of agitation is perceived as pure propaganda nowadays. Communists tried to alienate themselves from manipulative roots of propaganda: "The Bolsheviks never looked for and did not find devilishly clever methods to influence people's minds, to brainwash them. [...] They thought of propaganda as part of education" (Kenez, 1985, p. 8). The educative role of propaganda was influenced by the specific conditions in Russia, where the 
majority of rural population was illiterate, and, therefore, unable to grasp the ideas of Communism. Propaganda became an organizational activity, for communists the most important purpose was to be the first messenger, whose teaching would be accepted unconditionally. The sophistication of the message and its manipulative potential were of second importance. The situation was highlighted by V. Lenin, who put a theoretical background for communist media theory and identified three functions of the media under communist rule: propaganda, agitation and organisation (Lenin, 1901). The organisational function, assigned to the media by the communist rulers, reveals the essence of the Soviet system of 'public information and propaganda' and its ties with mass brainwashing. Democratic system promotes media as a unique platform for social and political understanding, as a place of public discussion and deliberation. Under communists, the media plays an instrumental role and leaves no space for public reflections. Mass brainwashing became a dream for the masters of the Soviet media, which was never publicly spelled and, fortunately, never came into being.

The above mentioned ways of understanding the brainwashing under the Soviet regime could be applied only retroactively, as the interrogation by $\mathrm{KGB}$, treatment in psychiatric clinics, or extensive Communist propaganda activities were never described as brainwashing. Paradoxically, the evidence from the Soviet side about practical implementation of brainwashing serve as indirect support for skepticism about the scientific origins of the concept and indirectly endorse conspiratorial nature of the phenomena.

\section{THE REBIRTH OF THE CONCEPT}

It would be rational to presume, that the end of the First Cold War could witness the death of the concept of brainwashing. In the place of its birth, on the West side of the Iron curtain, the idea had lost it previous appeal: the scientific verdict on irrationality of brainwashing was rigorous and irreversible, political potential was exhausted, and popular charm of the concept was irreversibly wasted. On the East side, the brainwashing remained barely known, the attempts to find connections between the concept and Soviet realities continued mainly as academic exercises. However, all the predictions about the demise of the concept appeared to be premature. If the frequency of the use of a word over time counted with the help of Google Search has any rationale, the use of 'brainwash' in English tells an appealing story: from the birth of the concept we observe a sharp rise in its use, which is followed by a short phase of moderate decline, which 
approximately coincides with the interlude between the fall of the Soviet empire and the beginning of the new tension between the East and the West. The Google Search statistics indicate, that today, 'brainwash' is used even more often than in the high days of the Cold War. How it was possible for the word, which was coined at the outset of the Cold War and revolved into one of the symbols of the time, to outlive the first great confrontation between democracy and communism so easily, and make a smooth transition into the period of the Second Cold War?

When the tension of the First Cold War began fading and some intellectual exchange between the two competing sides became possible, the declining concept of brainwashing was finally introduced on the East side of the Iron curtain. The concept slowly entered the everyday language; however, in the communist sphere of influence it never obtained a mystique meaning or was percepted as an imminent threat. Brainwashing was associated with everyday use and, at least in Lithuanian language, reminded a slang word or a metaphor. Some other linguistic peculiarities should be noted as well. In the West, washing (and brainwashing) could be understood as a deep action or an internal process, as a penetration inside, as ability to provoke essential changes. In the East washing (and brainwashing) never went deep inside the matter, it was identified as an external activity, which was able to scratch only at the cover of the phenomenon. To no surprise, after the fall of the Iron curtain, in the new aspiring democracies, the concept of brainwashing lacked any rational meaning of its own, and established itself as some peculiarity, imported from the still unknown 'capitalist world'.

The new temporary interpretation of brainwashing emerged after the final fall of Communism, and should be associated with aggressive assault of commercial advertising technologies, whose abrupt rise was shocking. At the very beginning of the new capitalist era the promotion of products had no rational meaning (Čereška, 2004). Central Europeans had lived in the world of scarcity for decades: during the Soviet times reports about production of new TV sets or refrigerators were communicated as political messages, with no commercial background. Because of supply shortages there was no need to persuade people to buy. The commercial advertising arrived to Central Europe earlier than prosperity, and the aspirations of population outpaced reality (Laar, 2010). The aggressive promotional activities of Western companies were hardly understandable for impoverished customers, who were unable to make sense of the fight of trademarks, which was targeted to the distant future and aimed to create loyalty of prospective consumers. The difference between the potential of the target audience and the behavior of 
the advertisers contributed to the misunderstanding of the functions of the advertising. The very practice of promotion, advertising, public relations, and similar activities instantly obtained negative connotation, the recently acquired concept of brainwashing suited to describe the new established practice.

The intimate relationship of brainwashing with black marketing or manipulative persuasion, which was impersonalized by such popular concepts as 'hidden persuaders' (Packard, 1980), were always understood as a reputational risk for the established PR or advertising industries, which used a lot of energy to sideline themselves from political activities or propaganda. Promotional industries were reluctant to acknowledge the similarity of employed methods and stressed ethical differences. The analogies with brainwashing, which emerged in the developing Central European markets, were highly undesirable. Fortunately brainwashing, as a nickname for advertising, marketing, or PR, was relatively quickly ousted from the public discourse as the promotional activities gained their natural and established position, which was compatible with the Western standards (Čereška, 2004).

Nevertheless, the newfound imaginative concept of brainwashing was not lost; it simply drifted towards a political realm. The process could be described as the return to original conspiratorial roots of brainwashing; however, we should note some important differences. In the post-Soviet space political brainwashing was associated not with personal persuasion, but acquired a meaning of mass coercion. This change was influenced by the short lived associations with advertising industries, although its roots should be traced back to the ideas of Plekhanov or Lenin.

The political changes in newfound democracies created a fertile ground for reinvention of the brainwashing as well. The new political parties found it hard to identify themselves with established ideological traditions. For example, in Lithuania at least two strong political parties claimed the legacy of social democracy; the center of political spectrum was especially crowded, as it was fashionable to be neither on the right, nor on the left. Ideological opacity, party building and electoral challenges encouraged political establishment to look for quick, but not necessary sustainable decisions; ideologies were replaced by political communication, and the means of communication became more important than the messages (Nevinskaite, 2006). The drift of political communication towards PR and marketing in Central Europe coincided with comparable processes in established Western democracies, and to so some extend even copied it. The 
UK aspiring prime minister of the 90's, Tony Blair and his 'Third Way' politics and hard dependence on spin doctoring, serve as an excellent example of communication supremacy over politics or ideology. However, the new established or reestablished democracies in Central Europe had lost decades of natural political evolution; for new entrants into politics the sudden shift towards empty slogans was especially dangerous and had a damaging impact on political culture. Political communication without ideological meaning and authentic moral narrative was labeled as brainwashing.

The rapprochement of political communication and brainwashing was accelerated by the new generation of Central European politicians and political parties, which could be referred as 'business-firm parties' (Just, Charvat, 2016). The new political entities constructed their political activities according to the business models of their founders, who happened to be successful businessmen with political aspirations. The outsourcing of party communication to professional PR companies became a usual practice, as it helped to rationalize the use of human and financial resources, however, impoverished political parties intellectually (Aleknonis, 2010). When a political party becomes "an organization with only one basic function - to mobilize immediate and superficial broad public support during elections" (Just, Charvat, 2016, p. 87), the brainwashing could gain a place at the center of such activities.

The reinvention of brainwashing in Central Europe half a century after its birth inevitably brought essential changes to the concept. The most visible and important was the shift of the target of brainwashing from a single person towards the mass audience. Instead of being a process, which happened in isolation, under gruesome conditions, with application of mysterious methods and techniques, the reinvented concept lost a significant part of original mystery and became a more natural everyday phenomenon, which resembled ordinary propaganda. The conspiratorial roots of the brainwashing were damaged, the whole image became blurred. The brainwashing drifted to intellectual and political periphery, lost its appeal, universality and favourable context. Under these circumstances it would be appropriate to ask: are the brainwashing of the 50's and 60's in the West and the brainwashing on the verge of the 20th and 21st centuries in the Central Europe comparable? However, the question is outdated. The reinvented concept of brainwashing quickly drifted into a new realm of international security politics. The process was facilitated by the rise of the new tension between Russia and the West, which was accelerated by the annexation of Crimea and followed by the battles in the Eastern part of Ukraine, support of 
the Kremlin of Syria regime, and rigorous Western answers and sanctions. The alarming situation refreshed geopolitical concerns which were slowly coming out of fashion after the end of the First Cold War. Subsequently, the conflict brought a new dimension into understanding of modern warfare, and simultaneously encouraged the new understanding of brainwashing.

\section{THE NEW MISUNDERSTANDINGS}

The beginning of the Second Cold War marks the third step of modern transformation of brainwashing: after a short period of commercialisation, brainwashing was politicized, and currently is entering a phase of weaponization (Waltzman, 2017), which could be described as the return to the original roots. According to the emerging narrative of the Second Cold War, the brainwashing is applied by the same principal agent (Russia), however the target of attacks, the field of brainwashing and its ideological background underwent essential modifications. Today, in Central Europe, brainwashing is understood not as a concentrated assault against an individual, but as sophisticated attack against the whole society, an attempt to change public opinion. The change of the target encourages the employment of the new technologies. If 'classical brainwashing' was associated with Pavlovian respondent conditioning, the reorientation towards mass persuasion demands other methods and encourages the sophisticated use of old and new media. Social media provides something special for modern interpretation of brainwashing, as contemporary social media platforms reach an extremely broad audience and creates imagined societies or information bubble. Simultaneously, it can create feelings of loneliness, which are the first condition for successful classical brainwashing.

The field, where brainwashing was executed during the First Cold War, was limited by the boundaries of the Communist bloc, or by prison walls inside the Communist countries. The short interlude between the two Cold Wars witnessed not only the fall of the hard boarders, but a creation of a completely new internet sphere. It is much more complicated to build barriers in this new field of communication, and even the Great Firewall of China performs worse than Soviet radio broadcast jamming, which was one of the most wasteful instruments of the First Cold War. It was unimaginable, that the old style of brainwashing could be performed on a mass scale inside the Western countries, today the field of brainwashing does not recognize any limits, the targets for attitude change could be easily found all over the world. 
The loss of its hard ideological component should be considered as the exceptional feature of the 'modernisation' of brainwashing, which was originally percepted as an indoctrination of the westerners with communist ideas. The front line of the First Cold War was relatively clear, as was based on ideological differences between communism and capitalism, liberal democracy and dictatorship of the proletariat. "Russia's outlook today is less bound to any ideology, and Moscow may be shrewder as a result" (Chivvis, 2017, p. 8). Ideological indifference opens new propaganda opportunities and encourages a search of a new content for the mind change. Communist Russia was attacking Western values and promoting a new way of life, which was labeled as communism, socialism, or 'mature socialism'. Modern Russia remains the principal critic of the West, however, this critique became strategic, not ideological. The Kremlin ideologists were replaced by strategists, who have nothing to offer, except some sort of condemnation of liberal values, denunciation of ruling elites, or doubts about the usefulness of democracy. The absence of clear ideological position makes Moscow brainwashing attempts less attractive and reasonable, simultaneously; it narrows the circle of devoted supporters. However, the lack of a clear target and cause rally unscrupulous technocrats, encourage their infamous inventiveness, which recognize no moral borders.

The current weaponization of brainwashing inevitably broadens the concept and creates a risk, that the loss of the precise meaning could blur the concept and diminish its attractiveness. This is a double risk, as the historical understanding of brainwashing is not entirely forgotten and preserves it's relatively precise meaning. The reinvented concept of brainwashing can become an everyday phenomenon, a synonym of propaganda, and loose its strategic meaning. The changes of the concept originate not from its actual inventors, but from the innovators, who are inspired by the idea of the Second Cold War and new dangers from Russia. These innovators happen to be concentrated in the Central Europe, especially in those countries which left the Russian sphere of influence and joined NATO, and pretend to be experts of old communist and new oligarchic Russia.

For a time being reinvention of the brainwashing remains contradictive. On the East flank of NATO, where the concept underwent gradual change, the brainwashing already established itself as an important tool, which helps explain the new strategic challenges and threats. In the West the fading concept of brainwashing had lost its old meaning, however, the significant part of political establishment is inclined to interpret a refreshed understanding of brainwashing as a fantasy of the Easterners. The 
conspiratorial roots of brainwashing and scientific verdict on the concept had not been forgotten, attempts to revive brainwashing is understood as a fantasy or vague reminiscences of the past. The excellent example of such misunderstanding could be the performance of Lithuanian Foreign Minister Linas Linkevičius on the BBC Hardtalk show (Linkevičius, 2016a). The politician publicly declared, that Russia "brainwashes Europe". The idea was misinterpreted, however the statement was highly appreciated by Lithuanian media (Linkevičius, 2016b).

The comparison of the First and the Second Cold War often looks like an exaggeration for left leaning intellectuals and politicians, who nurture a long lasting tradition of support to Russian regimes. The Stalin industrialization served as an excuse of massive repressions between the two World Wars, the merit of the Red Army in fight against Nazis was used as a justification of Stalin crimes against humanity. Contemporary tolerance to the Kremlin assaults could be based on pragmatic economic grounds, however it is shortsighted.

In order to find consensus on how to deal with the Russian question, the European Union and NATO allies should rely on the comparative interpretations of new strategic realities, otherwise the very descriptions of propaganda attacks, information warfare operations, or brainwashing could create the basis for misunderstanding. The Western allies bring together different experiences from the period of the First Cold War, which some of them had spent on the opposing sides of the Iron Curtain. The Alliance has a long lasting experience of integration of former enemies or rivals, which dates back to 1955, when the Second World War foe West Germany joined the NATO, or 1990, when East Germany, a longtime member of the rival Warsaw Pact, was integrated into the United Germany. All the new members, who joined the NATO since 1999, had experienced the communist rule or occupation. Mentality changes are more complicated and last longer, than integration of command structures, reorganization of military units or their rearmament. For contemporary NATO allies, the concept of brainwashing is not just another difference in experiences of the First Cold War, but one of those exemplary concepts, which reveal the endemic contradictions, which do not depend on the good will of the partners.

The principal aim of information warfare is to conquer not lands, but minds of people; the spread of mistrust among allies could be one of the principal aims of propaganda war. The contradictory revival of the concept of brainwashing encourages the division of the united NATO front, the conflicting understanding of brainwashing by the allies and neglectance of 
these contradictions leads not only towards ridiculous miscommunication among politicians or the media. It disturbs the climate of cooperation, raises doubts about the political rationale of the information security as a whole, and the professionalism of specialists of information operations in particular. The conceptual misunderstandings undermine mutual trust within the Alliance, devalues Eastern members of the NATO as experts on Russian policy, and encourages their image as reckless champions of hawkish policy.

\section{CONCLUSION}

The recent political developments and security challenges encourage rethinking and re-evaluating the concept of brainwashing. However, the hope that contemporary research is capable to provide a mature understanding of brainwashing is premature. It is symbolic that one of the first scholars, who tried to provide the 21st century outlook into the concept, was neuroscientist Kathleen Taylor, who argues, that "Brainwashing is not a magic bullet, a short cut to thought control. Rather, it is a complex phenomenon which uses increasingly well-understood psychological processes to wreak its havoc" (Taylor, 2004, p. xi). The renewed awareness of medical sciences into the subject serves as a clear evidence, that public belief in the magic of brainwashing outlived its time. In order to actualise a half a century old verdict of her colleagues, Taylor had to employ the contemporary knowledge of human brains, which lead to similar conclusions: "Brainwashing is above all a social and political phenomenon, and our best defences will also be at the level of society: only politics can maximize protection. To defend ourselves we need to favour certain kinds of political approaches-those which emphasize the importance of personal freedoms-and avoid belief systems which value cultures, organizations, or societies more highly than individual human beings" (Taylor, 2004, p. xi).

The Cold War legacy of brainwashing is encrypted into contemporary understanding of the concept and inevitably influences its new meaning, which became less specific and more universal. However, the comprehension of brainwashing continues to alternate between instrumental and political understanding. The broadened concept becomes more blurred, although the lack of precision compensates the potential loss of mystery and allows the brainwashing to preserve an image of almighty technique. The use of reinvented concept of brainwashing is not limited to the sphere of the Second Cold War, where it became a source of misunderstandings 
between the allies. Brainwashing (especially its new form e-brainwashing, i.e., propaganda activities in virtual sphere) could be employed to explain any hated phenomena, which is hard to interpret. As the recent electoral victories and referendum results brought some discontent to the political establishment and mainstream media, brainwashing became a favourite tool to explain Donald Trump's electoral victory or the Brexit vote results. During the First Cold War, brainwashing was a tool, preferred on the right side of the political spectrum, as it played a flagship role in the fight against communism. Today's shift to the left is totally accidental, and could be explained by the fact, that victories do not require public analysis from the winners, while the losers are looking for the scapegoats.

The recent modernisation of the old concept into e-brainwashing reminds mass persuasion activities; however, its focus on mass influence is partly new and incompatible with classical understanding of brainwashing. However, e-brainwashing literary inherits the narrative of a mental A-bomb. The real A-bomb was an American invention, which was quickly 'stolen' by the Russians. The rise of the Internet tells a similar story: the innovation, which originated in a democratic society and manifests the freedom of expression, is creatively misused by authoritarian regimes against the creators. In this context, brainwashing remains a mature conspiracy theory, whose credibility is challenged by political and technological changes. However, today, brainwashing is more useful not for politicians or a new generation of Cold War warriors, this innovative threat is principally misused by PR and data companies, which "are happy to propagate this myth because it's good for business" (Bartlett, 2018, p. 15).

\section{REFERENCES}

ALEKNONIS, G. (2010). Visuomenė ir žiniasklaida užburtame rate. Nuo sistemos vergo iki 'ketvirtosios valdžios'. In: MESONIS, G. (ed.) Regnum est: 1990 m. Kovo 11-osios Nepriklausomybes Aktui - 20. Liber Amicorum Vytautui Landsbergiui: mokslo straipsniu rinkinys. Vilnius: Mykolo Romerio universiteto Leidybos centras, 2010, pp. 673-689.

ANON. (1979). Lietuva bolševiku okupacijoje. Chicago: Jūrų šaulių kuopa Klaipėda, 1979.

ANON. (1999). Psichiatrinés inkvizicijos siautëjimas Lietuvoje. Vilnius: Šventaragio slènis, 1999.

ANUŠAUSKAS, A. (2000). KGB ir lietuvių visuomenè - Slaptasis karas 19541991 metais. In: Darbai ir dienos. No. 21, 2000, pp. 233-283. 
ANUŠAUSKAS, A. (2012). Teroras, 1940-1958 m. Vilnius: Versus aureus, 2012. APPLEBAUM, A. (2012). Iron curtain: The crushing of Eastern Europe 19441956. Toronto: McClelland \& Stewart, 2012.

BAGUŠAUSKAS, J. (2004). Komunistų partijos ideologinė apologetika slopinant tautos pasipriešinimą (1944-1953 m.). In: Genocidas ir rezistencija. No. 16, 2004, pp. 41-54.

BARTLETT, J. (2018). Big Data is Watching You. In: Spectator, March 24, 2018, p. 15.

BERLET, C. (2009). Toxic to democracy. Conspiracy Theories, Demonization, Scapegoating. Somerville: Political Research Associates. [online]. Available at: <http://www.publiceye.org/conspire/toxic2democracy/ Tox2Dem-1.pdf>. [Accessed 06-09-2019].

BIDERMAN, A. (1957). Communist attempts to elicit false confessions from Air Force prisoners of war. In: Bulletin of the New York Academy of Medicine. Vol. 33, No.9, 1957, pp. 616-625.

BUKOVSKY, V., GLUZMAN, S. (1974). A Manual on Psychiatry for Dissenters. [online]. Available at: <https://backchannelsblog.files.wordpress. com/2018/01/46bc6-amanualonpsychiatryfordissenters.pdf $>$. [Accessed 06-09-2019].

CARRUTHERS, S. (2009). Cold War Captives: Imprisonment, Escape, and Brainwashing. Berkeley: University of California Press, 2009.

CHIVVIS, C. (2017). Understanding Russian "Hybrid Warfare" and What Can be Done About It. Santa Monica: RAND Corporation. [online]. Available at: <https://www.rand.org/content/dam/rand/pubs/testimonies/CT400/ CT468/RAND_CT468.pdf>. [Accessed: 06-09-2019].

CONDON, R. (2004). The Manchurian Candidate. New York: Pocket Books, 2004.

ČEREŠKA, B. (2004). Reklama: teorija ir praktika. Vilnius: Homo liber, 2004. DUNNE, M. (2013). A Cold War State of Mind: Brainwashing and Postwar American Society. Amherst: University of Massachusetts Press, 2013.

GERASIMOV, V. (2013). The Value of Science in prediction. [online]. Available at: $\quad$ https://inmoscowsshadows.wordpress.com/2014/07/06/thegerasimov-doctrine-and-russian-non-linear-war/\#more-2291>. [Accessed: 06-09-2019].

HOFSTADTER, R. (1996). The Paranoid Style in American Politics. Cambridge: Harvard University Press, 1996.

HOLMES, M. (2016). The 'Brainwashing' Dilemma. In: History Workshop Journal. Vol. 81, No. 1, 2016, pp. 285-293. [online]. Available at: <https:// doi.org/10.1093/hwj/dbw007>. [Accessed: 06-09-2019]. 
HUNTER, E. (1951). Brainwashing in Red China. New York: Vanguard Press, 1951.

HUNTER, E. (1956). Brainwashing: The story of men who defied it. New York: Farrar, Straus and Cudahy, 1956.

HUNTER, E. (1962). Brainwashing, from Pavlov to Powers. Linden, N.J.: Bookmailer, 1962.

JUST, P., CHARVAT, J. (2016). Business-Firm Parties and the Czech Party System after 2010. In: Politics in Central Europe. Vol. 12, No. 3, 2016, pp. 83-110.

KENEZ, P. (1985). The Birth of the Propaganda State: Soviet Methods of Mass Mobilization, 1917-1929. Cambridge: Cambridge University Press, 1985.

KILLEN, A., ANDRIOPOULOS, S. (2011). Editors' Introduction On Brainwashing: Mind Control, Media, and Warfare. In: Grey Room. No. 45, 2011, pp. 7-17. [online]. Available at: <https://doi.org/10.1162/ GREY_e_00047>. [Accessed: 06-09-2019].

KUKLYTĖ, B. (2007). Disidentų kalinimas Sovietų Sajungos psichiatrijos ligoninėse 1918-1988 m. In: Genocidas ir rezistencija. No. 1 (21), 2007, pp. 31-53.

LAAR, M. (2010). The power of freedom: Central and Eastern Europe after 1945. Tallinn: Unitas Foundation, 2010.

LEE, M. (2011). Conspiracy Rising. Conspiracy Thinking and American Public life. Santa Barbara, CA: Praeger, 2011.

LENIN, V. (1901). Where to Begin? [online]. Available at: <https://www. marxists.org/archive/lenin/works/1901/may/04.htm\#fwV05E001>. [Accessed: 06-09-2019].

LENIN, V. (1902). What is to be done? [online]. Available at: <https://www. marxists.org/archive/lenin/works/1901/witbd/iii.htm>. [Accessed: 06-09-2019].

LIFTON, R. (1989). Thought reform and the psychology of totalism: A study of "brainwashing" in China. Chapel Hill and London: The University of North Carolina Press, 1989.

LINKEVIČIUS, L. (2016a). Foreign Minister of Lithuania on BBC Hardtalk. [online]. Available at: <https://www.youtube.com/ watch?v=dLITkFiZGZg>. [Accessed: 06-09-2019].

LINKEVIČIUS, L. (2016b). Linas Linkevičius BBC „Hardtalk“: Rusija plauna smegenis visai Europai. [online]. Available at: <https://www.15min.lt/ naujiena/aktualu/lietuva/linas-linkevicius-bbc-hardtalk-rusija-plaunasmegenis-visai-europai-56-717754>. [Accessed 06-09-2019]. 
LITTLEJOHN, S. W., FOSS, K. A., \& OETZEL, J. G. (2017). Theories of Human Communication. Long Grove, Illinois: Waveland Press, 2017.

LUTHI, L. (2008). The Sino-Soviet Split: Cold War in the Communist World. Princeton: Princeton University Press, 2008.

MEERLOO, J. (1956). The Rape of the Mind. New York: Universal Library, 1956.

MELLEY, T. (2012). Covert Sphere: Secrecy, Fiction, and the National Security State. NY: Cornell University Press, 2012.

NEVINSKAITĖ, L. (2006). Žiniasklaidos kokybè: nepatenkinti publikos lūkesčiai. In: ŽILIUKAITĖ, R., (ed.) Neatrasta galia: Lietuvos pilietinès visuomenés žemélapis. Vilnius: Versus Aureus, 2006, pp. 180-198.

PACKARD, V. (1980). The hidden persuaders. Brooklyn: Ig Publishing, 1980.

RASMUSSEN, A. (2014). Public opening remarks by NATO Secretary General Anders Fogh Rasmussen at the doorstep prior to the meetings of NATO Foreign Affairs Ministers. [online]. Available at: <http://www.nato.int/ cps/en/natolive/opinions_111210.htm?selectedLocale=en $>$. [Accessed 06-09-2019].

ROBIN, R. (2009). The Making of the Cold War Enemy: Culture and Politics in the Military-Intellectual Complex. Princeton: Princeton University Press, 2009.

SARGANT, W. (1957). Battle for the Mind. A Physiology of Conversion and Brain-Washing. Baltimore: Penguin Books, 1957.

SCHEIN, E. (1960). Brainwashing. Cambridge: Center for International Studies, MIT, 1960.

TAYLOR, K. (2004). Brainwashing: The science of thought control. Oxford: Oxford University Press, 2004.

TRIMAKAS, K. (1981). Psichiatrijos piktnaudojimas Sovietų Sąungoje. In: Aidai. No. 4, 1981. [online]. Available at: <http://www.aidai.eu/index. php?option $=$ com_content $\&$ view $=$ article $\& i d=7466:$ is $\&$ catid $=409: 4-$ liepa-rugpjtis\&Itemid=464>. [Accessed 06-09-2019].

VAISETA, T. (2014). Balsai iš sovietinių psichiatrijos ligoninių. Savojo aš sampratos skunduose. In: Darbai ir Dienos. No. 62, 2014, pp. 187-207.

VAN VOREN, R. (2015). Fifty years of political abuse of psychiatry - no end in sight. In: Ethics, Medicine and Public Health. Vol. 1, No. 1, 2015, pp. 4451.

WALTZMAN, R. (2017). The Weaponization of Information. The Need for Cognitive Security. Santa Monica: RAND Corporation, 2017. [online]. Available at: <https://www.rand.org/pubs/testimonies/CT473.html>. [Accessed: 06-09-2019]. 